\title{
WALI NIKAH DALAM KITAB FATH AL-QADÎR KARYA IBNU HIMMAM (TINJAUAN DESKRIPTIF ANALITIS TEMATIS)
}

\author{
Dwi Sagita Akbar \\ KUAKec.Ampek.Angkek, dwisagitaakbar@gmail.com
}

\begin{tabular}{l|l|l} 
Diterima: 25Juli 2018 & Direvisi : 20 November 2018 & Diterbitkan: 30 Desember 2018 \\
\hline
\end{tabular}

\begin{abstract}
Marriage has terms and harmony that have been established both in the Qur'an and in the Hadith. One of the conditions in a marriage contract is the presence of a parent (guardian) and a representative. Trusteeship, which was originally an ancient Arab culture that eventually became the Prophet's Sunnah was an absolute requirement for women to be able to do a marriage. What is meant by guardian in marriage is someone who acts on behalf of the bride in a marriage contract. Indeed there is no single verse of the Koran that clearly (explicitly) explains the existence of a guardian in a marriage contract. But there are only verses that can be understood to require the existence of a guardian as in the letter Al-Baqarah verse 221. This article briefly describes the guardian of marriage contained in the Fath Qadir Ibn Himmam. The book of Fath al-Qadir by Ibn Himmam was chosen to be the main source of study because it was one of the monumental works of all times in the field of Islamic Sciences especially for the study of Islamic law and was born from one of the famous Jurists to the present. The story of the Fath Qadir book is explained that according to Ibn Himmam guardianship in marriage is divided into two types, namely nadab / musthab and ijbar guardianship.
\end{abstract}

Keywords: Wali, Nikah, Fath al-Qadir, Ibnu Himmamm.

\begin{abstract}
Abstrak
Pernikahan mempunyai syarat dan rukun yang sudah ditetapkan baik dalam Alquran maupun dalam Hadits. Salah satu syarat dalam akad nikah adalah terdapatnya orang tua (wali) dan seorang wakil. Perwalian, yang awalnya merupakan satu kebudayaan Arab kuno yang akbirnya menjadi Sunnah Nabi adalah syarat mutlak bagi perempuan untuk bisa melakukan pernikahan. Yang dimaksud dengan wali dalam perkawinan adalah seseorang yang bertindak atas nama mempelai perempuan dalam suatu akad nikah. Memang tidak ada satu ayat Alquran yang secara jelas (eksplisit) menjelaskan keberadaan wali dalam akad perkawinan. Akan tetapi yang ada hanya ayat-ayat yang dapat dipahami menghendaki adanya wali seperti dalam surat Al-Baqarah ayat 221. Tulisan ini memaparkan secara singkat mengenai wali nikeah yang terdapat dalam kitab Fath Qadir Ibnu Himmam. Kitab Fath al-Qadir karya Ibnu Himmam dipilih untuk menjadi sumber utama kajian karena itu adalah salah satu karya monumental sepanjang zaman dalam bidang Ilmu Keislaman khususnya untuk kajian bukum Islam dan labir dari salah satu abli fikih ternama bingga saat ini. Dalm kitab Fath Qadir dijelaskan babwa menurut Ibnu Himmam perwalian dalam pernikahan terbagi kedalam dua macam, yaitu perwalian yang nadab/musthab dan perwalian ijbar.
\end{abstract}

Kata Kunci: Wali, Nikah, Fath al-Qadir, Ibnu Himmamm.

\section{PENDAHULUAN}

Pernikahan dapat berjalan selain karena akad nikah, juga karena adanya sebuah proses sosiologis antara pasangan yang saling menyukai dan mampu hidup bersama dalam menempuh bahtera rumah tangga. Pernikahan sendiri mempunyai syarat dan rukun yang sudah ditetapkan baik dalam Alquran maupun 
dalam Hadits. Salah satu syarat dalam akad nikah adalah terdapatnya orang tua (wali) dan seorang wakil. Perwalian, yang awalnya merupakan satu kebudayaan Arab kuno yang akhirnya menjadi Sunnah Nabi adalah syarat mutlak bagi perempuan untuk bisa melakukan pernikahan.

Yang dimaksud dengan wali dalam perkawinan adalah seseorang yang bertindak atas nama mempelai perempuan dalam suatu akad nikah. Akad nikah dilakukan oleh dua pihak yaitu pihak laki-laki yang dilaksanakan oleh mempelai laki-laki sendiri dan pihak perempan yang dilaksanakan walinya.Menurut pendapat jumhur ulama, keberadaan seorang wali dalam akad nikah merupakan suatu keniscayaanyang mengandaikan tidak sahnya akad perkawinan yang tidak dilakukan oleh wali. Skema ini berlaku untuk semua perempuan dewasa atau masih kecil, masih perawan atau sudah janda.

Memang tidak ada satu ayat Alquran yang secara jelas (eksplisit) menjelaskan keberadaan wali dalam akad perkawinan. Akan tetapi yang ada hanya ayat-ayat yang dapat dipahami menghendaki adanya wali seperti dalam surat Al-Baqarah ayat 221. Tuntutan dalam ayat ini dikemukakan Allah SWT kepada wali untuk tidak mengawinkan anak perempuannya dengan laki-laki musyrik. Namun di samping itu terdapat pula ayat Alquran yang memberikan pengertian perempuan itu kawin sendiri tanpa memakai wali. ${ }^{1}$

Tulisan ini memaparkan secara singkat mengenai wali nikah yang terdapat dalam kitab Fath Qadir Ibnu Himmamm. Sehingga nantinya dapat dipahami bagaimana Ibnu Himmamm memandang wali dalam pernikahan. Kitab Fath al-Qadir karya Ibnu Himmamd dipilih untuk menjadi sumber utama kajian karena itu adalah salah satu karya

\footnotetext{
${ }^{1}$ Amir Syarifuddin, Garis-garis Besar Fiqh, (Jakarta : Kencana, 2007), hal. 90
}

monumental sepanjang zaman dalam bidang Ilmu Keislaman khususnya untuk kajian hukum Islam dan lahir dari salah satu ahli fikih ternama hingga saat ini.

\section{PENGERTIAN WALI NIKAH}

Perwalian, dalam literatur fiqh Islam disebut dengan al-walayah (الولاية). Secara etimologi, dia memiliki beberapa arti. Di antaranya adalah cinta (المحبّة) dan pertolongan بَغْضُهُمْ أَوْلِيَاءُ seperti dalam penggalan ayat (نصرة) بَعْضِ Ayat 71 surat at-Taubat (9) ; juga berarti kekuasaan/otoritas (السلطة والقدرة) seperti dalam ungkapan al-wali (الوالى), yakni orang yang

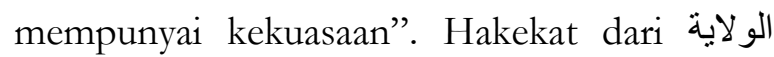
adalah “ "نولي الامر" (mengurus/menguasai sesuatu). ${ }^{2}$

Adapun yang dimaksud dengan perwalian dalam terminologi para fuqaha (pakar hukum Islam) seperti yang dikemukakan Wahbah Al-Zuhaili ialah:

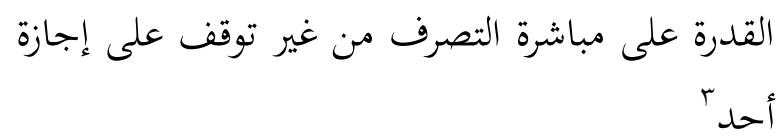

"Kemampuan untuk langsung bertindak tanpa bergantung kepada irin seseorang”.

Sejalan dengan itu menurut Amir Syarifuddin, yang dimaksud dengan wali secara umum adalah seseorang yang karena kedudukannya berwenang untuk bertindak terhadap dan atas nama orang lain. ${ }^{4}$

Dengan demikian dapat dipahami bahwasanya yang dimaksud dengan wali secara universal adalah orang yang karena kedudukannya bertindak atas nama orang lain tanpa izin seseorang.

${ }^{2}$ Muhammad Amin Suma, Hukum Keluarga Islam Di Indonesia, (Jakarta: PT Raja Grafindo Persada, 2005), hal. 134

${ }^{3}$ Wahbah Az-Zuhaili, Fighu Al-Islam $W a$ Adilatubu Juz VII, (Beirut : Daar Al-Fikr, t,th), hal. 186

${ }^{4}$ Amir Syarifuddin, Hukum Perkawinan Islam di Indonesia, (Jakarta : Kencana, 2006), hal. 69 
Hanafiyah membagi perwalian kepada tiga bagian :

Pertama wali atas jiwa (Wilayah 'ala alNafs) yang wilayahnya meliputi kepada urusanurusan kepribadian seperti mengawinkan, mengajar dan sebagainya, dan menjadikan kekuasaan ini milik bapak dan kakek.

Kedua kekuasaan atas harta (Wialayah ala al-Mal) yang kekuasaannya mengenai masalah harta benda seperti mengembangkan harta, menjaga serta membelanjakan. Kekuasaan ini juga milik bapak dan kakek, atau orang yang memberi wasiat oleh mereka berdua.

Ketiga wilayah atas jiwa dan harta secara bersamaan, dan dalam hal ini pun berkuasa tetap bapak dan kakek. ${ }^{5}$

Dalam memahami apa yang dimaksud dengan wali nikah, beberapa ulama telah memberikan definisi secara khusus untuk menjelaskan mengenai wali nikah ini, di antaranya :

Abdurrahman Al-Jaziri mengemukakan definisi wali nikah :

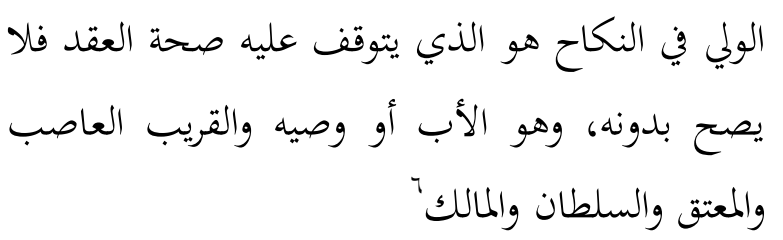

"Wali di dalam nikah adalah orang yang mempunyai puncak kebijaksanaan atas keputusan yang baginya menentukan sabnya akad (pernikahan), maka tidaklah sah suatu akad tanpa dengannya, ia adalah ayah atau kuasanya dan kerabat yang melindungi, mu 'tiq, sulthan dan penguasa yang berwenang".

Sayyid Sabiq juga memberikan definisi mengenai wali nikah dalam Fikih Sunnah yaitu :

الولاية حق شرعي، ينفذ بمقتضاه الامر على الغير جبرا

$$
\text { عنه }
$$

${ }^{5}$ Wahbah Az-Zuhaili, Fiqhu Al-Islam Wa Adilatubu Juz VII,..., hal.187

${ }^{6}$ Abdurrahman Al-Jaziri, Kitab Al-Fiqh 'ala AlMadz̧abil Arba'ah Juz IV, (Beirut, Dar-Al-Kutub AlAlamiyah,t.t), hal. 29
"Suatu yang harus ada menurut syara' yang bertugas melaksanakan bukum atas orang lain dengan paksa".

Dari penjelesan mengenai perwalian di atas dapat kita pahami bahwa perwalian dapat dipahami dalam bentuk yang luas dan dapat dipahami dalam bentuk yang khusus. Maka dalam memahami wali apa yang dimaksudkan maka perlu kita sesuaikan dengan konteks pembicaraan. Karena dalam memahami wali secara khusus perlu adanya hubungan dengan konteks yang menjadi pembatas sehingga pemahaman terhadap wali tidak menyimpang dari apa yang seharusnya.

Dengan melihat beberapa ketentuan tentang pengertian wali dapat dipahami bahwa wali yang dimaksud di sini adalah orang yang mengasuh orang yang berada di bawah perwaliannya, dan dalam hal ini cenderung pada wali dalam suatu pernikahan. Wali adalah orang/pihak yang memberikan izin berlangsungnya akad nikah antara laki-laki dan perempuan. Wali nikah hanya ditetapkan bagi pihak perempuan. ${ }^{8}$ Wali nikah adalah orang yang berakad dalam suatu pernikahan, sehingga dalam tersambungnya ijab dan qabul dalam suatu pernikahan dilakukan oleh wali dan mempelai laki-laki yang melangsungkan pernikahan.

\section{DASAR PENSYARIATAN WALI NIKAH}

Adapun yang menjadi dasar hukum wali adalah Alquran dan hadis, mereka mengutip ayat Alquran yang berkaitan dengan wali dan juga mengutip hadis-hadis yang berbicara mengenai wali dalam pernikahan di antaranya :'

${ }^{7}$ Sayyid Sabiq, Fikih Sunnah Juz II, (Beirut : Dar Al-Kitab Al-'Arabi, 1977), hal. 125

'Sudarsono, Sepuluh Aspek Agama Islam, (Jakarta: Rineka Cipta, 1994), hal. 235

${ }^{9} \mathrm{Kamal}$ al-Din Muhammad ibn al-Himmam alHanafi, Sharkh Fathul Al-QodirJuz III, (Beirut : DarAlfikr,1995), hal. 247-250 


\section{$\underline{\text { Dalil Alquran }}$}

Firman Allah yang terdapat dalam surat Al-Baqarah ayat 232:

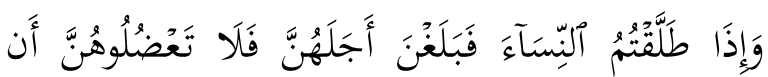

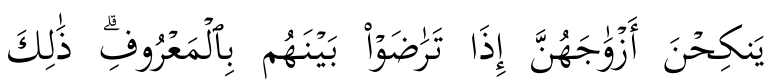

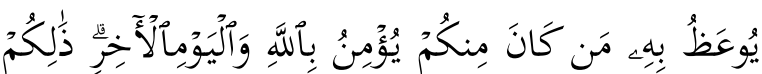

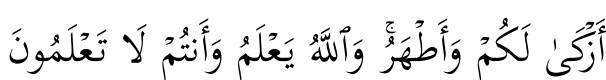

"Apabila kamu mentalak isteri-isterimu, lalu habis masaiddahnya, maka janganlah kamu (para wali) menghalangi mereka kawin lagi dengan bakal suaminya, apabila telah terdapat kerelaan di antara mereka dengan cara yang ma'ruf. Itulah yang dinasehatkan kepada orang-orang yang beriman di antara kamu kepada Allah dan hari kemudian. Itu lebih baik bagimu dan lebih suci. Allah mengetabui, sedang kamu tidak mengetahui".(Q.S. Al-Baqarah :232)

$\underline{\text { Dalil hadis }}$

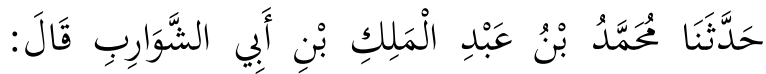

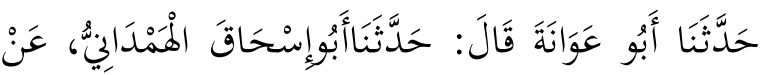

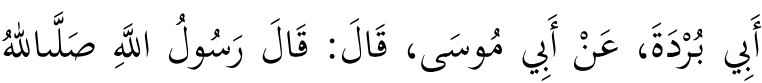

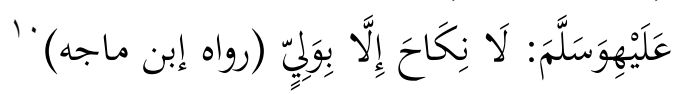

"Telah menceritakan kepada kami MuHimmamd bin 'Abdil Malik bin Abi Asy-Syawarib dia berkata : telah menceritakan kepada kami Abu 'Awanah dia berkata: telah menceritakan kepada kami Abu Ishaq Al-Hamdani dia berkata : dari Abu Burdab Ibnu Abu Musa, dari ayabnya Radiyallaahu'anbu dia berkata Rasulullab salallabu alai wa sallam bersabda: "Tidak ada nikab kecuali dengan wali”. (H.R. Ibnu Majah)

Adapun hadis lain yang menjadi dasar dalam pensyari atan wali

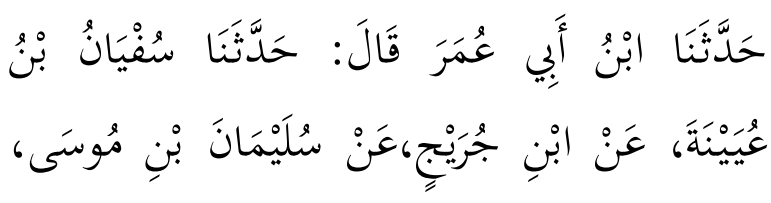

${ }^{10}$ Ibnu Majah, Sunan Ibnu Majab Juz. I, Muhaqqiq : Muhammad Fuad Abdi Al-Baqi, (Fishal 'Isa Al-Babi Al-Halbi- Dar Ihya`Al-Kitab Al-`Arabiah,t,t), hal. 605

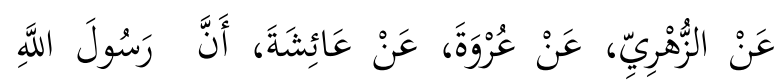

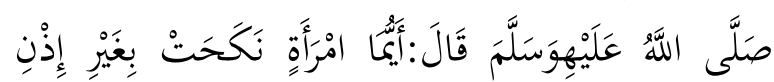

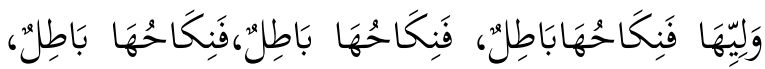

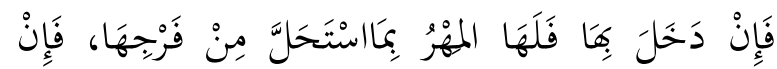

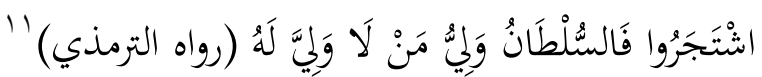
"Telah Menceritakan kepada kami Abi Umar dia berkata : telah menceritakan kepada kami Sufyan bin 'Uyainah, dari Ibnu Juraij, dari Sulaiman bin Musa, dari Az-Zubri, dari, 'Urwah, dari 'Aisyah babwa Rasulullah saw bersabda: "Perempuan yang nikah tanpa irin walinya, maka nikahnya batil. Jika sang laki-laki telah mencampurinya, maka ia wajib membayar maskawin untuk kehormatan yang telah dihalalkan darinya, dan jikea mereka bertengkar maka penguasa dapat menjadi wali bagi wanita yang tidak mempunyai wali" (H.R. AtTirmidhzi)

\section{EKSISTENSI WALI DALAM PERNIKAHAN}

Menurut mayoritas ulama, wali nikah merupakan salah satu rukun pernikahan. Wali dikatakan sebagai rukun pernikahan artinya harus ada dalam pernikahan, tanpa adanya wali, pernikahan tersebut dianggap tidak sah. Terutama pernikahan dari orang yang belum mukallaf. ${ }^{12}$ Dalam akad pernikahan, wali berkedudukan sebagai orang yang bertindak atas nama mempelai perempuan dan dapat pula sebagai orang yang dimintai persetujuannya untuk kelangsungan pernikahan tersebut.

Terdapat perbedaan pendapat di kalangan ulama mengenai kedudukan wali sebagai orang yang bertindak atas nama mempelai perempuan dalam melakukan akad. Adapun bagi mempelai yang masih kecil baik laki-laki maupun perempuan, jumhur ulama

${ }^{11}$ At-Tirmdhzi, Sunan Tirmidhzi Juz III, Muhaqqiq dan Mu`aliq : Ahmad Muhammad Syakir dan Muhammad Fuad 'Abdi Al-Baqi, (Kairo : Darul Hadis, 2010), hal. 399

12Soemiati, Hukum Perkawinan, Jakarta : Rineka Cipta, 2009), hal. 42 
seperti Imam Malik, Syafi ${ }^{\text {ec }}$ dan Hambali sepakat bahwa kedudukan wali sebagai rukun atau syarat dalam akad nikah. Alasannya adalah mempelai yang masih kecil tidak dapat melakukan akad dengan sendirinya, oleh karena itu akad tersebut dilakukan oleh walinya. Namun, Imam Abu Hanifah berpendapat bahwa wanita boleh mengawinkan dirinya sendiri. Bagi perempuan yang telah dewasa baik ia janda atau masih perawan, ulama berbeda pendapat. Hal ini disebabkan tidak adanya dalil pasti yang dapat dijadikan rujukan.

Terdapat beberapa perbedaan pendapat terkait perwalian tersebut. Ulama Syafi iyah dan Hanabilah berpendapat bahwa setiap akad pernikahan dilakukan oleh wali, baik perempuan itu dewasa atau masih kecil, janda atau perawan, akalnya sehat atau tidak. Tidak ada hak sama sekali bagi perempuan tersebut untuk mengakadkan pernikahannya. Wali merupakan syarat sahnya nikah, apabila perempuan menikah tanpa wali, maka nikahnya batal.

Ulama Hanafiyah dan Syi ah Imamiyah berpendapat bahwa bagi pernikahan anak kecil baik akalnya sehat atau tidak, diwajibkan adanya wali yang akan mengakadkan pernikahannya. Sedangkan bagi perempuan yang sudah dewasa dan akalnya sehat, boleh melangsungkan sendiri akad pernikahannya tanpa adanya wali. Menurut beliau, wali bukan merupakan syarat sahnya nikah, akan tetapi hukumnya sunnah boleh ada wali boleh pula tidak ada, yang penting harus ada izin orang tua pada saat menikah, baik ia perempuan maupun laki-laki.

Ulama Malikiyah menurut riwayat Asyhab, wali merupakan suatu yang mutlak dalam pernikahan dan tidak sah pernikahan tanpa adanya wali. Namun, menurut riwayat Ibnu Qasim, adanya wali hanyalah sunnah hukumnya dan tidak wajib.
Ulama Zhahiriyah berpendapat bahwa untuk perempuan yang masih kecil atau akalnya tidak sehat diwajibkan adanya wali. Sedangkan bagi perempuan yang sudah dewasa wajib adanya izin dari wali. Yang dimaksud izin wali ialah bukan diakadkan oleh wali. ${ }^{13}$

Selain itu, menurut UU no. 1 tahun 1974, tidak dijelaskan mengatur wali nikah, akan tetapi disyaratkan harus ada izin orang tua apabila calon pengantin belum berumur 21 tahun. ${ }^{14}$

\section{WALI NIKAH DALAM KITAB FATH QADIR}

Pembahasan mengenai wali nikah juga dikemukakan oleh Ibnu Himmam dalam Kitabnya Fath Qadir. Pembahasan tersebut dijelaskan secara panjang lebar dalam bab $A l$ Auliya wa Al-Akfa: Untuk lebih jelasnya penulis akan mencoba menjelaskan poin penting terkait wali nikah dalam kitab Fath Qadirini.

Dalam kitab Fath Qadir karya Ibn Himmam menjelaskan bahwa perwalian dalam pernikahan dibagi kedalam dua macam : yaitu perwalian nadab/istibbab dan perwalian ijbar. Kemudian dijelaskan bahwa perwalian nadab atau istihabab tersebut berlaku terhadap perempuan yang sudah baligh berakal baik perempuan tersebut masih berstatus perawan maupun berstatus janda. Sedangkan perwalian ijabar merupakan perwalian yang berlaku terhadap perempuan yang masih kecil baik anak kecil tersebut berstatus perawan maupun janda, maka di sini berlaku perwalian ijbar tersebut. $^{15}$

Dalam kitab tersebut juga disebutkan bahwa penetapan perwalian disebabkan karena empat sebab yaitu : Al-Qarabah (Hubungan

\footnotetext{
${ }^{13}$ Amir Syarifuddin, Hukum Perkawinan Islam di Indonesia,..., hal. 69-67

${ }^{14}$ Moh. Idris Ramulyo, Hukum Perkawinan Islam, (Semarang : PT Toha Putra, 2010), hal. 224

${ }^{15} \mathrm{Kamal}$ al-Din Ibnu Hamam Al-Hanafi, Syarak.h Fath Qadir Juz III,..., hal. 255
} 
kekerabatan), Al-Milk (Kepemilikan), AlWala, dan Imamah (Penguasa). ${ }^{16}$

Perwalian Al-Qarabah (kekerabatan) adalah perwalian yang ditetapkan berdasarkan adanya hubungan darah/adanya kekerabatan antara wali dan orang yang berada di dalama) perwalianya, baik kekerabatan itu bersifat dekat seperti halnya bapak, kakek, saudara atau akibat kekerabatan yang bersifat jauh seperti halnya anak laki-laki paman dari pihak ibu, dan anak laki-laki paman dari pihak laki-laki. ${ }^{17}$ Urutan perwalian dari sebab kekerabatan adalah seperti di bawah ini:

1. Anak dan anaknya anak sampai nasab ke bawah

2. Bapak dan kakek yang asli dan nasab keatasnya

3. Saudara laki-laki sekandung, dan saudara laki-laki sebapak, serta anak laki-laki

4. Saudara sekandung dan sebapak dan nasab kebawahnya

5. Paman sekandung, dan paman sebapakb) serta anak-anak laki-lakinya dan nasab kebawahnya.

6. Kemudian setelah mereka itu orang yang memerdekakan budak

7. Dan kerabat 'asabah-nya secara nasab. ${ }^{18}$

Perwalian Al-Milk (kepemilikan) adalah perwalian akibat adanya kepemilikian yaitu antara seorang majikan terhadap budakbudaknya. Dengan demikian seorang majikan mempunyai hak mutlak terhadap budakbudaknya, sehingga seorang majikan tidak memerlukan keridhaan dari budaknya tersebut. Hal ini karena seorang budak merupakan milik

\footnotetext{
${ }^{16} \mathrm{Kamal}$ al-Din Ibnu Hamam Al-Hanafi, Syarakh Fath Qadir Juz III,..., hal. 255

17`Alauddin Abi Bakr Ibn Mas'ud, Badai'u AlShonai', Juz II, (Beirut : Dar Al-Kitab Al-`Ilmiyah, 1986), hal. 238-239

${ }^{18}$ Kamal al-Din Muhammad ibn al-Himmam al-Hanafi, Sharkh Fathul Al-QodirJuz. III,..., hal. 277
}

majikannya secara keseluruhan yang ada pada dirinya secara mutlak. ${ }^{19}$

$$
\text { Perwalian Al-Wala (karena }
$$

memerdekakan) ini dibagi menjadi dua macam: ${ }^{20}$

\section{Perwalian al-'Atiqah}

Yaitu perwalian yang disebabkan karena memerdekakan seorang budak. Maka dalam hal perwalian karena memerdekakan budak ini Hanafiyah menganggap perwaliannya dapat menjadi perwalian yang wajib dan dalam kondisi lain dapat menjadi perwalian istihbab (sunat). Maksudnya di sini ketika seorang yang telah dimerdekakan tersebut hendak menikah namun dia tidak memiliki wali asabah dari keluarganya maka orang yang memerdekakan tersebut adalah walinya. Namun, jika ada ‘asabah dari keluarganya maka dalam hal ini orang yang memerdekakan tidak wajib untuk menjadi wali baginya. ${ }^{21}$

Perwalian al-Muwalah

Yaitu perwalian akibat adanya sebuah akad antara dua orang untuk menolongnya dan membayarkan denda dan perwalian akibat adanya sebuah akad antara dua orang untuk menolongnya dan membayarkan dendanya jika dia melakukan tindakan kriminal, serta mengurusnya jika dia meninggal, oleh karena itu hak menikahkan juga berada di bawah kekuasannya. ${ }^{22}$

Perwalian yang disebabkan karena seseorang memiliki kekuasaan di suatu daerah dan memiliki kewenangan sebagai wali. Perwalian Pengusa ini juga dapat dilakukan oleh wakilnya (penguasa) tersebut. Untuk cakupan perwalian pemimpin ini di antaranya seperti qadhi. Dalam hal ini dia memiliki kewenangan untuk menikahkan orang yang mempunyai beberapa sebab.

19`Alauddin Abi Bakr Ibn Mas'ud, Badai'u AlShonai', Juz II,...hal. 23

$20^{`}$ Ibid. hal. 252

21`Ibid.

22`Ibid. 
Perwalian beralih ke penguasa apabila terdapat salah satu syarat di antara dua syarat berikut:

Pertama, apabila tidak ada sama sekali wali asal yang akan menikahkan, maka perwalian beralih ke wali penguasa.

Kedua, apabila wali `adhal, maksudnya ketika wali asal enggan untuk menikahkan seseorang padahal pernikahan tersebut dilakukan dengan orang yang sekufu', maka dalam hal ini penguasa wajib menikahkan orang tersebut, dan apabila penguasa menolak untuk menikahkannya maka penguasa tersebut dianggap telah membuat mudharat sedangkan eksistensi penguasa adalah untuk menolak suatu kemudharatan. ${ }^{23}$

Hal yang manarik dikemukakan oleh Ibnu Himmam dalam kitabnya bahwa dia menyebutkan dalam pembahasan perwalian dalam pernikahan ini diawali dengan perwalian yang mandubah (sunnah). Dalam hal ini banyak pendapat dari kalangannya. Sehingga dalam perwalian ini dia hanya menjelaskan pendapat dari ulama-ulama mazhabnya terdahulu yang mana terdapat tujuh riwayat terkait dengan perwali yang sunnab ini.

Di antara pendapat tersebut sebagaimana yang dikemukakan oleh Imam Abu Hanifah kebolehan untuk perempuan yang sudah baligh berakal langsung untuk mengakadkan pernikahannya sendiri serta pernikahan perempuan selain dirinya secara mutlak. ${ }^{24}$

Dalam kitab Al-Mabsuth karangan Syarakhsi juga dijelaskan pendapat Imam Abu Hanifah yang demikian dengan membatasi jika calon suaminya tidak sekufu maka wali mempunyai hak untuk menghalangi pernikahan tersebut.

23`Alauddin Abi Bakr Ibn Mas'ud, Badai'u AlShonai, Juг II,...hal. 252

${ }^{24} \mathrm{Kamal}$ al-Din Muhammad ibn al-Himmam al-Hanafi, Sharkh Fatbul Al-QodirJuz III,..., hal. 255
Perwalian terhadap perempuan yang merdeka, sudah dewasa dan baligh, menurut Imam Abu Hanifah bentuk perwalian terhadapnya merupakan perwalian yang sunah bukanlah sesuatu yang wajib. Dengan demikian boleh seorang perempuan menikahkan dirinya sendiri dengan seorang laki-laki serta dia juga yang mengakadkan pernikahan tersebut baik dengan laki-laki yang sekufu' atau tidak sekufu', baik walinya ridha ataupun tidak ridha, maka nikahnya sah. Namun, dalam hal ini wali mempunyai hak untuk menghalangi pernikahan tersebut jika suami dari perempuan tersebut tidak sekufu atau mahar yang diberikan kurang dari marah mitsil yang menjadi hak perempuan. ${ }^{25}$

Abu Yusuf juga berkomentar mengenai hal ini yang dengan pendapat tidak diperbolehkannya menikahnya seorang wanita atas dirinya sendiri dengan seorang pria baik sekufu ataupun tidak ketika dia masih mempunyai wali. Lalu beliau kembali mengatakan, jika seorang suami sekufu maka nikahnya boleh, dan jika suaminya tidak sekufu maka nikahnya tidak boleh. Kemudian beliau kembali mengatakan nikah yang seperti itu sah baik suaminya sekufu maupun tidak. ${ }^{26}$

Begitu juga dengan Imam Tohawi yang menyebutkan bahwa untuk kembali kepada pendapat Abu Yusuf yang menyebutkan tidak boleh perempuan melakukan akad pernikahan kecuali dengan wali. ${ }^{27}$

Kemudian dalam kitabnya Ibnu Himam juga menjelaskan bahwa alasan dari hak ijbarnya wali adalah melihat keadaan calon mempelai yaitu masih kecil, hal ini berbeda dengan apa yang dikemukakan oleh Imam

\footnotetext{
${ }^{25}$ Sulaiman Al-Asyqar, dkk, Masail fi Fighi alMuqarrin, (Iran : Dar-An-Nafis, 1997), hal. 171

${ }^{26} \mathrm{Kamal}$ al-Din Muhammad ibn al-Himmam al-Hanafi, Sharkh Fathul Al-QodirJuz. III,..., hal. 256. Lihat juga Muhammad bin Abi Sahal Aimmah asSarakhsy, Al-Mabsuth Juz III,..., hal. 10

${ }^{27} \mathrm{Kamal}$ al-Din Muhammad ibn al-Himmam al-Hanafi, Sharkh Fathul Al-QodirJuz III,..., hal. 256
} 
Syafi i bahwa alasan dari perwalian ijbar adalah karena biker nya seorang mempelai perempuan. Hal ini sebagaimana yang dijelaskan dalam kitab Fathul Qadir sebagai berikut :

Agaknya terdapat perbedaan mendasar mengenai eksistensi wali dalam pernikahan yang dikemukakan dalam kitab Fath Qadir ini. Karena dari beberapa penjelasan ketika yang hendak menikah perempuan yang sudah dewasa baik perempuan tersebut masih perawan ataupun janda sebagaimana yang dikemukakan di atas dikategorikan ke dalam perwalian nadab/istibbab. Yang berarti perwalian terhadap perempuan tersebut bukan perwalian yang diwajibkan oleh Ibnu Himmam. Dan hal ini di dasari oleh beberapa pendapat ulama serta dalil-dalil yang akan dikemukakan selanjutnya. Tentu hal ini berbeda dengan apa yang telah dikemukakan oleh Jumhur ulama, yang berpendapat :

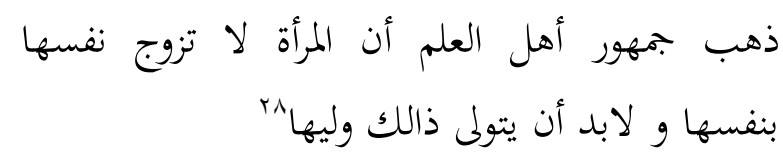

"Menurut Jumbur Abli Ilmu bahwa perempuan tidak menikabkan dirinya sendiri dengan dirinya sendiri, dan mestilah dalam hal itu dia mewalikan pernikahan tersebut kepada walinya"

Adapun kerangka berfikir yang disusun oleh Ibnu Himmam terkait dengan wali nikah ini, juga berdasarkan dalil-dalil Alquran maupun Sunnah, juga menyertakan dalil qiyas, yaitu dengan mengemukakan beberapa ayat Alquran yang memiliki indikasi untuk mendukung penjelasan di atas tersebut, yaitu :

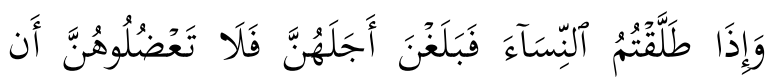

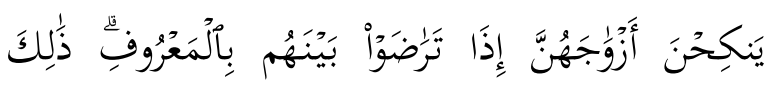

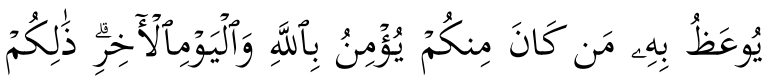

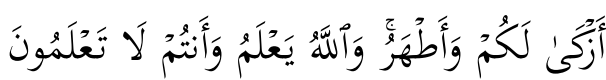
${ }^{28}$ Sulaiman Al-Asyqar, dkk, Masail fi Fiqhi al-
Muqarrin,..., hal. 170
"Apabila kamu menalak istri-istrimu, lalu habis iddabnya, maka janganlah kamu (para wali) menghalangi mereka kawin lagi dengan bakal suaminya, apabila telah terdapat kerelaan di antara mereka dengan cara yang ma'ruf. Itulah yang dinasibatkan kepada orang-orang yang beriman di antara kamu kepada Allah dan hari kemudian. Itu lebih baik bagimu dan lebih suci. Allah mengetabui dan kamu tidak mengetahui" (Q.S. Al-Baqarah: 232)

Ayat di atas menjelaskan bahwa hal tersebut melarang para wali unutuk melarang perempuan menikah dengan orang yang mereka pilih. Karena larangan melakukan pernikahan tersebut berada di tangan para walinya.

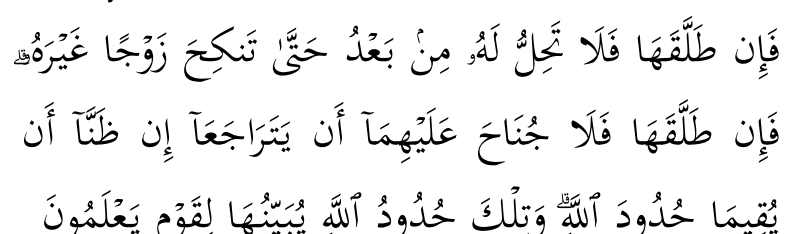

"Kemudian jika suami mentalaknya (sesudah talak. yang kedua), maka perempuan itu tidak halal lagi baginya hingga dia kawin dengan suami yang lain. kemudian, jikea suami yang lain itu menceraikannya, maka tidak ada dosa bagi keduanya (bekas suami pertama dan istri) untuk kawin kembali jïka keduanya berpendapat akan dapat menjalankan bukum-bukum Allah. Itulah bukum-bukum Allah, diterangkannya kepada kaum yang mau mengetahui." (Q.S. Al-Baqarah : 230)

Ayat di atas terdapat kata kerja iَنَكْكَ dan يَنْكْنَ yang memberikan pengertian bahwa penyandaran fi il (kata kerja) adalah kepada fåil (pelaku). Sehingga secara hakikat penyandaran fi il (kata kerja) adalah kepada fa il (pelakunya) dengan artian bahwa kata kerja نَ يَنْكِحْنَ pelaku pernikahan secara hakiki adalah si perempuan.

Dengan demikian dapat dipahami bahwa yang melakukan pernikahan dari penggalan kata tersebut adalah si perempuan secara langsung tanpa disyaratkannya wali karena pelaku hakiki dari fi il (kata kerja) 
adalah fa'il (pelakunya) yaitu perempuan itu sendiri. ${ }^{29}$

Kemudian didukung dengan hadis :

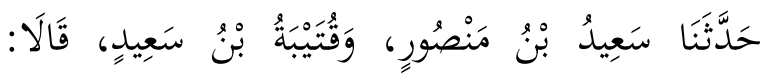

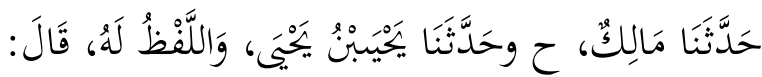
قُلْتُ لِمَالِلكِ: حَدَّثَكَ عَبْدُ اللهِ بْنُ الْفْضْلِ، عَنْ نَافِعِع

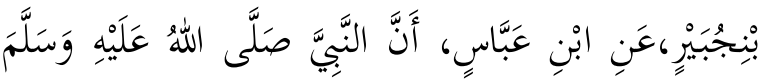

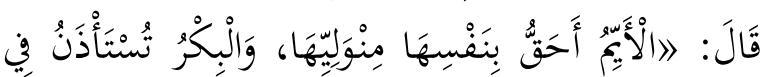

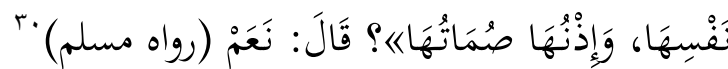

"Telah menceritakan kepada kami Säid bin Manshur dan Qutaibab bin Sa ¿id, mereka berdua telah berkata : telah menceritakan kepada kami Yabya bin Yabya, dan Lafazh menurutnya, dia berkata : aku telah berkata kepada Malik: telah menceritakan kepada engkau 'Abdullah bin Fadbli, dari Nafi bin Jubair, dari Ibnu 'Abbas, babwa Nabi Salallabu alaibi wa sallam telah bersabda: wanita yang tidak bersuami lebib berbak terhadap dirinya sendiri daripada walinya, dan perawan meminta izin kepadanya dan izin wanita yang perawan adalah diamnya?, dia berkata : benar " (H.R Muslim).

\section{Ibnu Himmam menjelaskan}

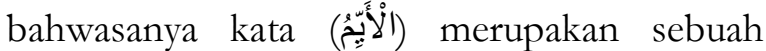
sebutan untuk seorang wanita yang tidak memiliki ikatan pernikahan (suami), baik dia itu perawan ataupun janda, dan ini merupakan pengertian yang benar menurut ahli bahasa. ${ }^{31}$ Oleh karena itu hadis ini menunjukkan bahwasanya seorang wanita yang tidak memiliki pasangan hidup memiliki hak dan dalam hak tersebut ia memiliki hak untuk

${ }^{29}$ Kamal al-Din Muhammad ibn al-Himmam al-Hanafi, Sharkh Fathul Al-QodirJuz. III,..., hal. 259, Lihat juga 'Alauddin Abi Bakr Ibn Mas'ud, Badai'u AlShonai', Juz II,...hal. 248

${ }^{30}$ Muslim, Shabih Muslim, Juz. I, ( Indonesia : Maktabah wa Matba ah Putra Semarang, t,t,), hal. 594

${ }^{31}$ Kamal al-Din Muhammad ibn al-Himmam al-Hanafi, Sharkh Fathul Al-QodirJuz III,..., hal. 259. Lihat juga Muhammad bin Abi Sahal Aimmah asSarkhsy, Al-Mabsuth Juz III,..., hal. 12 menikahkan dirinya sendiri baik dia perawan ataupun janda.

Hadis di atas senada dengan hadis :

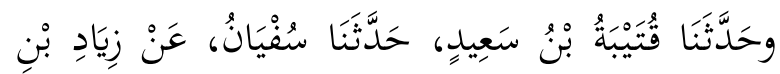

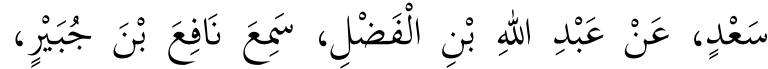

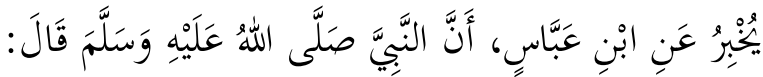

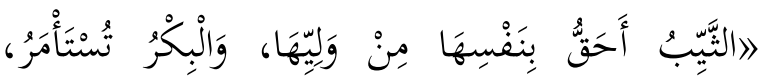

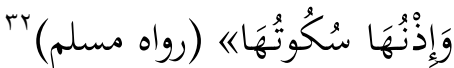

"Telah menceritakan kepada kami Qutaibah bin Sa id, telah menceritakan kepada kami Sufyan, dari Zivad bin Sa ï, dari Abdillah bin Fabli, dia telah menedengar Nafi bin Jubai, dikabarkan dari Ibnu Abbas, sesunggubnya Nabi Salallabu alaibi wa sallah telah bersabda : janda lebih berhak terbadap dirinya dari walinya, dan perawan dimintai i₹in, dan izinya adalah diamnya” (H.R Muslim)

Dalam memahami hadis di atas Ibnu Himmam membenarkan bahwa janda lebih berhak terhadap dirinya dari walinya, namun dalam memahami kata (وَ) Hanafiyah berbeda pendapat, yaitu jika wajib meminta izin sesuai dengan lafazh yang ada di dalam hadis, hal tersebut merupakan suatu bentuk yang kontradiktif dengan hak ijbar wali, karena hadis di atas menuntut untuk melaksanakan suatu perkara atau menuntut untuk meminta izin kepada si perempuan. Sehingga lafazh hadis di atas memfaidahkan bahwasanya permintaan izin tersebut bertujuan untuk menanyakan ridha atau tidaknya si perempuan.

Dengan demikian dari lafazh yang ditetapkan atas hak bagi seorang janda untuk dirinya itu mutlak. Kemudian hal yang serupa menunjukkan untuk si perawan sebagaimana yang telah ditunjukkan bagi si perawan tersebut hak untuk dimintai izin. Maksud dari perintah meminta izin tersebut bahwa hal itu adalah landasan terhadap lebih berhaknya setiap janda dan perawan dengan lafazh yang khusus seakan-akan berbunyi : seorang janda

${ }^{32}$ Muslim, Shabih Muslim, Juz I,..., hal. 594 
lebih berhak terhadap dirinya dan seorang perawan lebih berhak terhadap dirinya pula. ${ }^{33}$

Dengan demikian dapat dipahami bahwa yang dimaksud dalam memahami hadis di atas adalah pada dasarnya perempuan dan janda lebih berhak dari pada walinya. Lafazh hadis di atas hanya berfaidah untuk menanyakan keridhaannya atau tidak. Bukan berarti perempuan di bawah perwalian ijbar, karena jika si perempuan berada di bawah perwalian ijbar maka bentuk meminta izin akan bertentangan dengan sifat ijbar yang dimiliki oleh bapak. Sedangkan redaksi hadis yang menunjukkan perempuan dimintai izin, hal ini disebabkan karena menurut kebiasaan peminangan perempuan dilakukan melalui walinya sehingga ketika perempuan dipinang maka dimintai izin keridhaannya atau tidak terhadap peminangan tersebut. Hal inilah yang dipahami Hanafiyah dari redaksi hadis di atas.

Jumhur ulama pun juga memakai hadis di atas dalam menguatkan pendapat mereka, namun perbedaan dalam memahami redaksi hadis di atas menghasilkan rumusan pemikiran yang berbeda. Dalam memahami hadis di atas jumhur memahami bahwa hadis di atas berbicara mengenai pengkhususan berhaknya janda terhadap dirinya sendiri dari pada walinya, sehingga mafhum mukhallafah yang dapat dipahami dari pemahaman jumhur tersebut adalah bahwa hak janda terhadap dirinya sendiri tersebut tidak terdapat di sana perempuan yang masih gadis. Sehingga pemahaman yang dihasilkan oleh jumhur adalah bahwa hanya janda yang mempunyai hak terhadap dirinya sendiri, sedangkan perempuan yang masih gadis tidak memiliki hak serupa sebagaimana hak janda terhadap dirinya sendiri. ${ }^{34}$

${ }^{33} \mathrm{Kamal}$ al-Din Muhammad ibn al-Himmam al-Hanafi, Sharkh Fathul Al-QodirJuz III,..., hal. 262

${ }^{34}$ Kamal al-Din Muhammad ibn al-Himmam al-Hanafi, Sharkh Fathul Al-QodirJuz III,..., hal. 262
Menurut Hanafiyah hadis di atas merupakan hadis yang shahih sehingga Hanafiyah menggunakan hadis tesebut. Sedangkan hadis-hadis yang lain yang berbicara mengenai perwalian yang digunakan jumhur dalam menguatkan pendapat mereka seperti hadis yang diriwayatkan dari Abi Musa, dan hadis yang diriwayatkan Aisyah :

وَعَنْ أَبِي بُرْدَةَ بْنِ أَبَي مُوسَى , عَنْ أَبِيهِ قَالَ : قَالَ

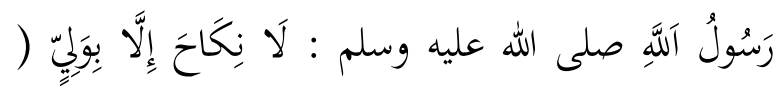

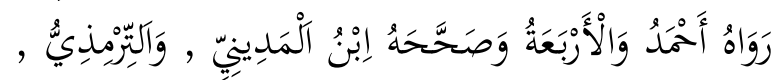

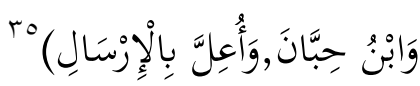

"Dari Abu Burdah Ibnu Abu Musa, dari ayabnya Radliyallaabu 'anbu babwa Rasulullah Shallallaabu 'alaibi wa Sallam bersabda: "Tidak sab nikah kecuali dengan wali." Riwayat Abmad dan Imam Empat. Hadis shabih menurut Ibnu al-Madiny, Tirmidri, dan Ibnu Hibban. Sebagian menilainya badis mursal".

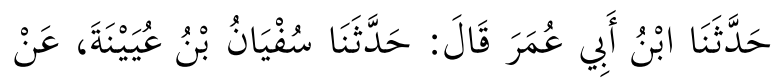

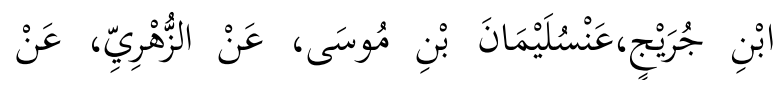

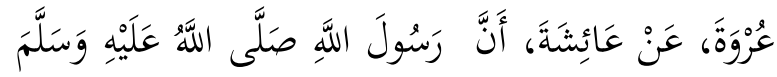

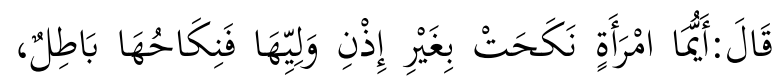

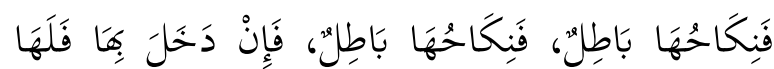

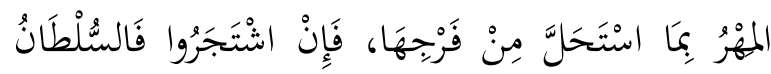

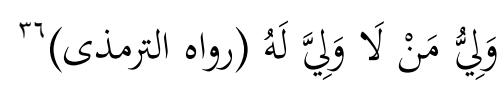

"Telah Menceritakan kepada kami Abi Umar dia berkata : telah menceritakan kepada kami Sufyan bin Uyainah, dari Ibnu Juraij, dari Sulaiman bin Musa, dari Az-Zubri, dari, 'Urwah,dari 'Aisyah bahwa Rasulullah saw bersabda: "Perempuan yang nikah tanpa iæin walinya, maka nikahnya batil. Jika sang laki-laki telah mencampurinya, maka ia wajib membayar maskawin untuk kehormatan yang telah

${ }^{35}$ Imam Muhammad bin Ismail Al-Kahlani, Subululssalam Syarah Bulughul Maram min Jami i Adilati Al-Abkamjuz. III, Bab Nikah, (Bandung : Pustaka Dahlan, t,th) hal. 117

${ }^{36}$ At-Tirmdhzi, Sunan Tirmidhzi Juz III,..., hal. 264 
dibalalkan darinya, dan jika mereka bertengkar maka penguasa dapat menjadi wali bagi wanita yang tidak mempunyai wali" (H.R. At-Tirmidhzi)

Sebagaimana yang dijelaskan dalam kitab Syarakh Fathul Qadir bahwa kedua hadis di atas merupakan hadis yang lemah. Menurut Ibnu Himmam hadis yang driwayatkan oleh Abi Musa merupakan hadis dhaif yang mudhtarib pada sanadnya. Kemudian hadis yang diriwayatkan Aisyah merupakan hadis yang diingkari oleh Az-Zuhri. ${ }^{37}$

Menurut Ibnu Himmam meskipun demikian ketiga hadis di atas dapat di kompromikan dengan menggunakan kaidah ushuliyyah :

\section{يجمل عمومه علي الخصوص \\ "Membawa yang umum terbadap yang khusus"}

Karena hadis yang dua di atas masih bersifat umum menurut Ibnu Himmam dan keumuman hadis di atas dapat dibawakan kepada hadis yang lebih khusus. Menurut Ibnu Himmam dengan kaidah tersebut maka dapat disetujui. Sehingga mereka mengaggap hadis yang diriwayatkan oleh Abi Musa dikhususkan dengan hadis yang diriwayatkan oleh Ibnu Abbas. Oleh karena itu untuk memahami dari hadis yang diriwayatkan oleh Abi Musa bahwa keberadaan (ل) nafi di sana merupakan nafi yang berfaidah untuk menyempurnakan dan hanya bersifat sunnah. ${ }^{38}$

Dan hadis Ibnu Abbas juga mengkhususkan hadis Aisyah yaitu dengan mentakwilkan bahwa kebatalan tersebut adalah bagi perempuan yang menikah tidak sekufu. Dan yang dimaksud dengan batal secara hakikat adalah melakukan pernikahan secara langsung tanpa mempertimbangkan sekufu atau tidaknya. Jika terjadi demikian maka diberikan hak kepada wali untuk menentang

${ }^{37}$ Kamal al-Din Muhammad ibn al-Himmam al-Hanafi, Sharkh Fathul Al-QodirJuz III,..., hal. 259

${ }^{38}$ Ibid., hal. 260 pernikahan dan dapat memfasakhan pernikahan tersebut.

Dengan demikian Ibnu Himmam berpendapat bahwa mafhum yang bisa dipahami apabila seorang perempuan yang sudah baligh berakal menikahkan dirinya sendiri dengan izin walinya maka pernikahan tersebut shahih. ${ }^{39}$

Disamping itu dalam kitab Fath Qadir juga mengemukakan dalil qiyas dalam permasalahan wali ini, yaitu dengan mengqiyaskan antara pernikahan perempuan yang sudah baligh berakal dengan jual beli yang dilakukan oleh perempuan yang baligh berakal. Dalam melaksanakan akad jual beli wanita dapat melakukan akad tersebut oleh dirinya sendiri. Sehingga dengan demikian apabila perempuan yang sudah baligh, dewasa dan berakal sehat dapat melaksanakan akad jual beli tentu mereka juga mampu untuk melaksanakan akad nikah dengan sendirinya. ${ }^{40}$ Hal ini disebabkan karena tidak ada perbedaan antara akad pernikahan dengan akad-akad yang lain. sehingga ketika perempuan mampun melaksanakan akad dalam bidang muamalat, tentu dia juga mampu melaksanakan akad dalam bidang perkawinan.

Berdasarkan hal inilah maka penetapan bagi perempuan yang sudah dewasa baligh berakal dapat langsung mengakadkan nikahnya sendiri. sedangkan dalam penetapan bahwa untuk perempuan yang belum dewasa baligh dan berakal maka ditetapkan baginya wali ijbar hal ini dikarenakan bahwa perempuan yang masih kecil masih dalam dunia ketidaktahuannya dengan perkara pernikahan dan akibat-akibat dari pernikahan. Oleh karena itu dalam penetapan wali ijbar hanya bagi anak kecil dengan illat bahwa dia tidak tahu dengan perkara nikah. Akan tetapi hal ini dapat diketahui pembatalan hak ijbar untuk

\footnotetext{
${ }^{39}$ Ibid., hal. 260

${ }^{40}$ Muhammad bin Abi Sahal Aimmah asSarkhsy, Al-Mabsuth Juz III,..., hal. 12
} 
memastikan dengan kebolehannya melakukan pernikahan, yaitu ketika jual beli dan berbelanja hal ini berlaku bagi siapa saja yang ketidaktahuannya itu karena tidak pernah menikah. ${ }^{41}$

Dengan melihat penjelasan yang dikemukakan oleh Ibnu Himmam terkait deng wali nikah di atas dapat disimpulkan bahwa Ibnu Himmam mengakui eksistensi wali ketika pernikahan dilakukan oleh anak yang belum baligh berakal baik masih perawan ataupun janda. Akan tetapi ketika seorang perempuan sudah dalam keadaan baligh berakal baik masih perawan maupun janda sepertinya Ibnu Himmam memberikan peluang kepada perempuan tersebut untuk melaksanakan akad pernikahannya sendiri meskipun tanda di dampingi oleh walinya.

Sebagaimana yang telah dikemukakan di atas, agaknya pendapat seperti ini juga merupakan manisfestasi dari pendapatpendapat imam-imam dalam mazhab yang dianut oleh Ibnu Himmam yaitu mazhab Hanafiyah. Sehingga cendrung kerangka berfikir yang dibangunnya merupakan perpanjangan dari kerangka berfikir para pengikut mazhab hanafiyah.

Sedangkan Wali mujbir memiliki hak untuk mengawinkan seseorang yang di dalam perwalianya, tetapi hak ijbar yang dimiliki oleh wali mujbir tidak bisa digunakan secara mutlak, karena di dalam hal ini ada obyek dari wali mujbir yaitu al-Soghiroh (anak perempuan kecil), ,illat (alasan) hukum yang digunakan oleh Ibnu Hamam bahwa al-Soghiroh adalah obyek dari penggunaan hak ijbar, karena al-Soghiroh dinilai mempunyai sebuah kekurangan yaitu kurang adanya aqal di dalam hal perkawinan, baik itu dalam pemilihan pasangan atau juga dalam hal aqad.

Ibnu Hamam juga berargumen bahwa wilayah wali mujbir adalah sebatas al-Sogbiroh

${ }^{41}$ Kamal al-Din Muhammad ibn al-Himmam al-Hanafi, Sharkh Fathul Al-QodirJuz III,..., hal. 261 (anak perempuan kecil) karena hukum pernikahan dipersamakan (qiyas) dengan hukum jual beli, yaitu di dalam jual beli dan perkawinan memiliki 'illat (alasan) hukum yang sama, karena di dalam jual beli ada sebuah aqad yang menjadikan status jual beli tersebut sah secara shari'at dan juga disyaratkan bagi orang yang beraqad jual beli harus orang yang sudah baligh, hal ini untuk menghindari adanya jual beli gharar (penipuan), kemudian di dalam pernikahan juga membutuhkan sebuah aqad, dan aqad tersebutlah yang menjadikan pernikahan menjadi sah secara shari'at, oleh karenanya semestinya aqad harus dilakukan oleh orang yang sudah baligh, apabila orang yang akan menikah adalah alSoghirob (anak perempuan kecil) maka agar aqad-nya sah secara shari'at, maka aqad tersebut harus di wakili oleh walinya.

\section{KESIMPULAN}

Dari paparan di atas dapat disimpulkan bahwa yang dimaksud dengan wali nikah secara umum adalah orang yang bertindak atas mempelai perempuan dalam melaksanakan pernikahan. Aturan tentang wali nikah ini secara eksplisit tidak diatur dalam Alquran akan tetapi ada indikasi yang memberikan gambaran bahwa adanya pensyari atan wali dalam pernikahan. Di dalam hadis, ada beberapa hadis yang berbicara secara jelas bahwa pernikahan bagi perempuan harus diwalikan oleh wali yang memiliki kewajiban terhadap diri perempuan tersebut. Oleh karena itu salah satu hadis juga berbicara bahwa tidak sah pernikahan tanpa adanya wali.

Dalm kitab Fath Qadir dijelaskan bahwa menurut Ibnu Himmam perwalian dalam pernikahan terbagi kedalam dua macam, yaitu perwalian yang nadab/musthab dan perwalian ijbar. Dalam kelanjutannnya bahwa ada perbedaan mengenai eksistensi wali ini dalam pernikahan menurut Ibnu Himmam. 
Bagi pernikahan perempuan yang sudah baligh berakal baik masih gadis ataupun janda eksistensi wali hanya semacam hal yang sunnah karena dalam hal ini perempuan diperbolehkan untuk langsung mengakadkan pernikahannya. Hal ini di dasari oleh beberapa pendapat ulama-ulama yang dikemukakan oleh Ibnu Himmam serta berdasarkan nash baik itu Alquran maupun Sunnah.

Sedangkan perwalian ijbar terbatas hanya bagi perempuan yang masih kecil, yang diistilahkan dengan Al-Shogirah. Dterhadap perempuan yang masih kecil dalam kitab Fath Qadir diwajibkan pernikahannya dengan diwakili oleh walinya. Hal ini dikarenakan perempuan yang masih kecil tidak mengetahui atau tidak memiliki pengalaman dalam melakukan pernikahan. Serta tidak mengetahui akibat-akibat dari pernikahan. Dengan demikian perwalian ijbar hanya berlaku bagi perempuan yang masih kecil.

Dengan demikian apa yang digagas oleh Ibnu Himmam dalam kitab Fath Qadir ada perbedaan dengan pendapat jumhur ulama yang menjelaskan bahwa bagi perempuan yang hendak menikah harud diwalikan oleh walinya. 


\section{DAFTAR KEPUSTAKAAN}

Al-Asyqar, Sulaiman, dkk, 1997, Masail fi Fiqhi al-Muqarrin, Iran : Dar-An-Nafis

Al-Hanafi, Kamal al-Din MuHimmamd ibn al-Himmam, 1995, Sharkh Fathul Al-Qodir, Beirut : Dar-Alfikr

Al-Jaziri, Abdurrahman, t.th, Kitab Al-Fiqh ala Al-Madæhabil Arba`ah, Beirut, Dar-Al-Kutub AlAlamiyah

Al-Kahlani, Imam MuHimmamd bin Ismail, t,th, Subululssalam Syarah Bulughul Maram min Jami $i$ Adilati Al-Abkam, Bandung : Pustaka Dahlan

Al-qur`an Karim

As-Sarakhsy, MuHimmamd bin Abi Sahal Aimmah, 1993, Al-Mabsuth, Beirut : Dar-al ma`rifah

At-Tirmdhzi, 2010, Sunan Tirmidhæri, Muhaqqiq dan Mu`aliq : Ahmad MuHimmamd Syakir dan MuHimmamd Fuad `Abdi Al-Baqi, Kairo : Darul Hadis

Majah, Ibnu, t,th, Sunan Ibnu Majah, Muhaqqiq : MuHimmamd Fuad Abdi Al-Baqi, Fishal 'Isa AlBabi Al-Halbi- Dar Ihya`Al-Kitab Al-`Arabiah

Mas'ud, 'Alauddin Abi Bakr Ibn, 1986, Badai’u Al-Shonai', Beirut : Dar Al-Kitab Al-'Ilmiyah

Muslim, t,th, Shabih Muslim, Indonesia : Maktabah wa Matba`ah Putra Semarang

Ramulyo, Moh. Idris, 2010, Hukum Perkawinan Islam, Semarang : PT Toha Putra

Sabiq, Sayyid, 1977, Fikih Sunnah, Beirut : Dar Al-Kitab Al-`Arabi

Soemiati, 2009, Hukum Perkawinan, Jakarta : Rineka Cipta

Sudarsono, 1994, Sepuluh Aspek. Agama Islam, Jakarta: Rineka Cipta

Suma, MuHimmamd Amin, 2005, Hukum Keluarga Islam Di Indonesia, Jakarta: PT Raja Grafindo Persada

Syarifuddin, Amir, 2006, Hukum Perkawinan Islam di Indonesia, Jakarta : Kencana 2007, Garis-garis Besar Fiqh, Jakarta : Kencana

Zuhaili, Wahbah, t,th, Fiqhu Al-Islam Wa Adilatubu, Beirut: Daar Al-Fikr 